\title{
Effects of arbuscular mycorrhizal fungi and doses of phosphorus on corn crop
}

\section{Fungos micorrízicos arbusculares e doses de fósforo na cultura do milho}

\author{
Raíssa de Araujo DANTAS ${ }^{1}$; Arminda Moreira de CARVALHO ${ }^{2}$; Mateus Costa COELHO ${ }^{3}$ \\ ${ }^{1}$ Engenheira Agrônoma, Mestranda em Agronomia; Universidade de Brasília - UnB; Faculdade de Agronomia e \\ Medicina Veterinária - FAV, Campus Darcy Ribeiro, CEP 70910-900, Caixa Postal 04508, Brasília/DF; e-mail: \\ rahdantas08@gmail.com \\ 2 Engenheira Agrônoma, Pesquisadora, Embrapa Cerrados, BR 020, km 18, Caixa Postal 08223, CEP 73010 - \\ 970, Planaltina/DF; e-mail: arminda.carvalho@embrapa.br \\ ${ }^{3}$ Engenheiro Agrônomo, Mestrando em Agronomia; Universidade de Brasília - UnB; Faculdade de Agronomia e \\ Medicina Veterinária - FAV, Campus Darcy Ribeiro, CEP 70910-900, Caixa Postal 04508, Brasília/DF; e-mail: \\ costa9001@hotmail.com
}

Recebido em: 26-07-2013; Aceito em: 17-04-2014

\begin{abstract}
Phosphorus is the most limiting nutrient for crop production in Cerrado soils. The arbuscular mycorrhiza is a symbiotic association with the roots, which involves the arbuscular mycorrhizal fungi and promotes benefits to the plants, as an enhanced capacity of absorbing nutrients from the soil, mainly phosphorus. This study was performed in a greenhouse at Embrapa Cerrados, Planaltina-DF, Brazil, and aimed to evaluate the influence of arbuscular mycorrhizal fungi and phosphorus doses in the yield of dry matter and in levels of phosphorus in the shoots of corn. A completely randomized experimental design with five treatments (doses of phosphorus and inoculation) and three repetitions was used. There were significant responses to the treatments with different doses of phosphorus. The inoculated treatment didn't differ significantly from the non-inoculated treatment with the same dose of the nutrient and from the treatment with application of $100 \mathrm{mg} \mathrm{kg}^{-1}$ of $\mathrm{P}$. The treatment with mycorrhizae showed the higher levels of phosphorus in the leaves. The results showed an interaction between $\mathrm{P}$ and $\mathrm{Mg}, \mathrm{K}$ and $\mathrm{Mn}$, being the first a synergistic interaction and the two other, antagonistic. The phosphorus fertilization and the mycorrhizal inoculation provide increments in the level of phosphorus in the shoots.
\end{abstract}

Additional keywords: dry matter; Gigaspora margarita; Oxisols; phosphorus absorption.

\begin{abstract}
Resumo
O fósforo é o nutriente mais limitante à produtividade das culturas em solos de Cerrado. A micorriza arbuscular é uma associação simbiótica com as raízes, que envolve os fungos micorrízicos arbusculares e que promove benefícios para as plantas, como aumentar a capacidade de absorção de nutrientes do solo, principalmente o fósforo. O presente estudo foi conduzido em casa de vegetação na Embrapa Cerrados, em Planaltina-DF, com o objetivo de avaliar a influência de fungos micorrízicos arbusculares e de doses de fósforo na produção de matéria seca e teor de fósforo na parte aérea do milho. O delineamento experimental foi inteiramente casualizado, com cinco tratamentos (doses de fósforo e inoculação) e três repetições. Houve efeitos significativos dos tratamentos com diferentes doses de fósforo. $O$ tratamento inoculado não diferiu significativamente do tratamento não inoculado com a mesma dose de $P$ e do tratamento com aplicação de $100 \mathrm{mg} \mathrm{kg}^{-1}$ de $P$. $O$ tratamento com micorriza apresentou níveis mais elevados de fósforo nas folhas de milho. Os resultados mostraram interação de $\mathrm{P}$ com $\mathrm{Mg}, \mathrm{K}$ e Mn, sendo a primeira uma interação sinérgica, e as outras, antagônicas. Portanto, a fertilização fosfatada e a inoculação com fungos micorrízicos arbusculares proporcionam incrementos de fósforo na parte aérea.
\end{abstract}

Palavras-chave adicionais: absorção de fósforo; Gigaspora margarita; Latossolos; matéria seca. 


\section{Introduction}

The cultivation in tropical soils presents favorable and limiting characteristics to agricultural production. Among the limitations for farming in these soils are the high acidity (low pH and high aluminum saturation) and the low natural fertility, especially in relation to phosphorus availability (ERNANI et al., 2002).

The high application of $P$ in weathered soils is justified by the intense retention of this nutrient, resulting in low content available to the plants, mainly due to the predominance of iron and aluminum sesquioxides minerals in these soils (NOVAIS \& SMYTH, 1999).

The economic feasibility of the production in soils with these characteristics is related to the adequate management of fertilizers, with lower quantities applied and higher efficiency of the phosphorus and nitrogen fertilizers (SANCHEZ \& SALINAS, 1981)

The arbuscular mycorrhizal fungi occur naturally in the agroecosystems and, through this symbiosis between the species of fungi and plants, promote an increase in the absorption of nutrients from the soil, especially phosphorus (MIRANDA et al., 2005). The association of plants with mycorrhizal fungi increases the efficiency of plants to absorb natural phosphorus and phosphorus added by fertilizers (MIRANDA, 2008).

The benefit effects of this symbiosis in plant growth, nutrient cycling and soil structure were shown in many articles (MIRANDA \& MIRANDA, 1997; VARMA \& HOCK, 1999; RILLIG \& MUMMEY, 2006). Therefore, arbuscular mycorrhizal fungi influence crop production, such as corn, and also expand the benefits for the subsequent crops (ESPINDOLA et al, 1998).

Agricultural research shows that agricultural practices such as liming and appropriate applications of fertilizers, crop rotation and use of cover plants/green manure in the productions systems may promote the spread of mycorrhizal fungi in the soil (BETHLENFALVAY \& LINDERMAN, 1992; JOHNSON et al., 1992; ABBOTT \& ROBSON, 1994; MIRANDA et al., 2001; 2005).

Arbuscular mycorrhizal fungi are obligatory symbionts and multiply only in presence of a host plant, because this organism depends on it to obtain photosynthates needed to survive (SMITH \& READ, 1997; VARMA \& HOCK, 1999). These fungi are naturally present in many soils, but certain species occur only in tropical soils (SIEVERDING, 1991). The occurrence and density of arbuscular mycohrrizal fungi depends on host plant characteristics, mycorrhizal fungi species, soil and climate (JOHNSON et al., 1992; SYLVIA \& WILLIAMS, 1992; HEIJDEN van der et al., 2003; STADDON et al., 2003). The community of this organism can be reduced or absent in land fallow, wet soils and soils amended by mineral exploration or by the intensive agriculture (BRUNDRETT, 1991; MARTINS et al., 1999); however, are higher in agrosystems that use less pesticides and that adopts practices such as minimum tillage and crop rotation (JASPER et al., 1989; MIRANDA et al., 2005; MIRANDA \& MIRANDA, 2007).

In the same rhizosphere, at least six or more species can be found (BONONI \& TRUFEM, 1983; BRUNDRETT, 1991; MIRANDA \& MIRANDA, 1997), with differences in effectiveness (BEVER et al., 1996); therefore, it is important to know which environmental conditions and agricultural practices favor the most efficient specie.

The use of soil management systems that promote the decrease of mycorrhiza colonization in the crops may lead to drastic consequences in the medium and long terms for the production and sustainability of the agroecosystems (ALGUACIL et al., 2008).

The increase in maize grain yield in response to fertilization with phosphorus, particularly in clayey Oxisols, denotes the nutrient demand by the crop (LOBATO, 1982).

Aiming a better use of this nutrient, studies have been conducted with mycorrhizae. COSTA et al. (2002), analyzing the inoculation of arbuscular mycorrhizal fungi (AMF), the soil acidity and phosphate fertilizers in maize growth, found that the combination of liming, low $P$ solubility, inoculated or non-inoculated, increases the shoot dry matter. This study proved that when the soil is handled correctly, promoting an increase in inoculum potential of indigenous species, there is no need of exotic mycorrhizal inoculation, because naturally occurring species can be effective and promote better absorption of nutrients. The authors also showed that symbiosis decreases with increase of phosphorus level.

REIS et al. (2008), in a greenhouse experiment testing different responses of phosphorus absorption in inoculated and non-inoculated maize, observed variability concerning efficiency and responsiveness of the crop to phosphorus and different mycorrhizae genotypes.

ORTAS \& AKPINAR (2011), also in a greenhouse experiment with mycorrhizae and maize, observed that the shoot growth and root colonization of maize genotypes depend on the mycorrhizal species. The previous authors and GILL et al. (2013) also observed the efficiency of symbiosis in $\mathrm{P}$ and $\mathrm{Zn}$ uptake and its importance for maize crops, based on grain yield.

Thus, the objective of this study was to evaluate the influence of arbuscular mycorrhizal fungi and doses of $P$ in the production of shoot dry matter and in the level of phosphorus in the shoots of corn (Zea mays L.). 


\section{Material and methods}

The study was performed in a greenhouse at Embrapa Cerrados, Planaltina-DF, Brazil, using pots containing $2 \mathrm{~kg}$ of soil each. The minimum and maximum temperatures in the greenhouse were $15^{\circ} \mathrm{C}$ and $29^{\circ} \mathrm{C}$, respectively. The soil, classified as Red Oxisol, clayey texture, Cerrado phase, was collected in an area of native vegetation, from the layer of $0-20 \mathrm{~cm}$, with the following chemical characteristics (after autoclaving): $\mathrm{pH}$ in water $5.15 ; 1.89 \mathrm{cmol}_{\mathrm{c}} \mathrm{dm}^{-3}$ of $\mathrm{Al}^{3+}$; $0.23 \mathrm{cmol}_{\mathrm{c}} \mathrm{dm}^{-3}$ of $\mathrm{Ca}^{2+}+\mathrm{Mg}^{2+} ; 0.18 \mathrm{cmol}_{\mathrm{C}} \mathrm{dm}^{-3}$ of $\mathrm{Ke} 1.61 \mathrm{mg} \mathrm{dm}^{-3}$ of $\mathrm{P}$.

The soil was previously steam sterilized, during two periods of 1 hour, at $120^{\circ} \mathrm{C}$ and then incubated with $4.5 \mathrm{t} \mathrm{ha}^{-1}$ of limestone $\left(\mathrm{CaCO}_{3}+\right.$ $\mathrm{MgCO}_{3}$ ) for 30 days.

The following fertilization was applied for each kilogram of soil in the treatments performed: $20 \mathrm{mg} \mathrm{kg}^{-1}$ of $\mathrm{N}, 150 \mathrm{mg} \mathrm{kg}^{-1}$ of $\mathrm{K}, 61 \mathrm{mg} \mathrm{kg}^{-1}$ of $\mathrm{S}, 2 \mathrm{mg} \mathrm{kg}^{-1}$ of $\mathrm{Zn}, 0.5 \mathrm{mg} \mathrm{kg}^{-1}$ of $\mathrm{B}, 0.1 \mathrm{mg} \mathrm{kg}^{-1}$ of Mo e $0.2 \mathrm{mg} \mathrm{kg}^{-1}$ of $\mathrm{Cu}$, in addition to different doses of phosphorus. The nutrient sources were ammonium nitrate $\left(\mathrm{NH}_{4} \mathrm{NO}_{3}\right)$, monocalcium phosphate monohydrate $\left(\mathrm{Ca}\left(\mathrm{H}_{2} \mathrm{PO}_{4}\right)_{2} \quad \mathrm{H}_{2} \mathrm{O}\right)$, potassium sulfate $\left(\mathrm{K}_{2} \mathrm{SO}_{4}\right)$, zinc sulfate $\left(\mathrm{ZnSO}_{4}\right)$, cupric sulfate pentahydrate $\left(\mathrm{CuSO}_{4} 5 \mathrm{H}_{2} \mathrm{O}\right)$, borax decahydrate $\left(\mathrm{Na}_{2} \mathrm{~B}_{4} \mathrm{O}_{7} \quad 10 \mathrm{H}_{2} \mathrm{O}\right)$ and ammonium molybdate tetrahydrate $\left(\left(\mathrm{NH}_{4}\right)_{6} \mathrm{Mo}_{7} \mathrm{O}_{24} \quad 4 \mathrm{H}_{2} \mathrm{O}\right)$. The phosphorus source was added four days before others nutrients to avoid soaking the soil (nutrients were applied in solution). The chemical analysis of the soil after the addition of lime presents the following chemical characteristics: $\mathrm{pH}$ in water 5.68; $0.18 \mathrm{cmol}_{\mathrm{C}} \mathrm{dm}^{-3}$ of $\mathrm{Al}^{3+}$; $4.60 \mathrm{cmol}_{\mathrm{C}} \mathrm{dm}^{-3}$ of $\mathrm{Ca}^{2+}+\mathrm{Mg}^{2+} ; 0.25 \mathrm{cmol}_{\mathrm{C}} \mathrm{dm}^{-3}$ of $\mathrm{Ke} 1.1 \mathrm{mg} \mathrm{dm}^{-3}$ of $\mathrm{P}$.

The experimental design was entirely randomized, with five treatments and three repetitions. The applied treatments were $\mathrm{T} 1(0 \mathrm{mg} \mathrm{kg}$

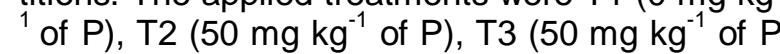
and arbuscular mycorrhizal fungi inoculation), T4 $\left(100 \mathrm{mg} \mathrm{kg}^{-1}\right.$ of $\left.\mathrm{P}\right)$ and T5 $\left(200 \mathrm{mg} \mathrm{kg}^{-1}\right.$ of $\left.\mathrm{P}\right)$. The treatments presented the following concentration of available $P$ after the application of phosphorus source: $1.43 \mathrm{mg} \mathrm{kg}^{-1}$ (T1), $2.35 \mathrm{mg} \mathrm{kg}^{-1}$ (T2), 2.91 $\mathrm{mg} \mathrm{kg}^{-1}$ (T3), $3.99 \mathrm{mg} \mathrm{kg}^{-1}$ (T4) and $9.13 \mathrm{mg} \mathrm{kg}^{-1}$ (T5).

The spores of the arbuscular mycorrhizal fungi for inoculation of the pots were obtained in the collection of Embrapa Cerrados and isolated, selected, introduced, and proliferated in a previously sterilized substrate (GERDEMANN \& NICOLSON, 1963), in the presence of host plants (MOSSE, 1981). The host plant used for proliferation of the spores was Stylosanthes guianensis, a plant that can be host of wide range of arbuscular mycorrhiza species (MIRANDA, 2008).
Three seeds, pretreated with nematicideinseticide Carbofuran, were sown in each pot after fertilization, and were thinned chopped later to two plants by pot when they reached the third pair of leaves. Thirty days after the cultivation, the corn plants were cut close to the soil and weighed for determination of the green biomass weight. The plant material was then oven dried at $60^{\circ} \mathrm{C}$ for three days, when the weighing for determination of dry matter and the leaf analysis were performed.

After cutting the plants, soil samples with roots were collected in the treatments with $50 \mathrm{mg}$ $\mathrm{kg}^{-1}$ of $\mathrm{P}$ without inoculation, $50 \mathrm{mg} \mathrm{kg}^{-1}$ of $\mathrm{P}$ with inoculation, and in the control treatment, for determination of the number of arbuscular mycorrhizal fungi spores in the soil and of the root colonization percentage.

The recovery of the spores was made through the wet sieving and decanting of $50 \mathrm{~g}$ of soil from each sample. The percentage of root colonization was determined according to the method of PHILLIPS \& HAYMAN (1970).

The macronutrients and micronutrients were extracted by wet digestion with perchloric acid and hydrogen peroxide heated to $350^{\circ} \mathrm{C}$ in digestion block for approximately one hour (ADLER \& WILCOX, 1985). The $\mathrm{K}$ was determined by flame photometry and the other elements ( $\mathrm{P}, \mathrm{Ca}, \mathrm{Mg}, \mathrm{S}, \mathrm{Bu}, \mathrm{Cu}, \mathrm{Mn}$ and $\mathrm{Zn}$ ) by plasma emission spectrophotometry. The nitrogen in the plant material was digested by sulfuricacid and the method of analysis was the semi micro Kjeldahl (SILVA, 1999).

The variance analysis was applied to evaluate the effects of the inoculation with mycorrhizal fungi and of the doses of phosphorus to the experiment in entirely randomized blocks. The test of mean comparisons (Tukey at $5 \%$ of significance) was applied to evaluate the treatments (STATISTICAL ANALYSIS SYSTEM INSTITUTE INC., 1999).

\section{Results and discussion}

Significant effects of the doses of phosphorus were observed in the yield of dry matter (Figures 1 and 2) and in the levels of some nutrients in the shoots of maize. As well as the phosphorus content, the levels of $\mathrm{K}, \mathrm{Mg}$ and $\mathrm{Mn}$ presented statistical differences among means (Table 1).

Comparing the treatments with and without phosphorus application, the increases in the yield of dry matter were $74 \%, 81 \%, 83 \%$ and $90 \%$, in the treatments with $50 \mathrm{mg} \mathrm{kg}^{-1}$ of $\mathrm{P}$, $50 \mathrm{mg} \mathrm{kg}^{-1}$ of $\mathrm{P}$ and inoculation, $100 \mathrm{mg} \mathrm{kg}^{-1}$ of $\mathrm{P}$, and $200 \mathrm{mg} \mathrm{kg}^{-1}$ of $\mathrm{P}$, respectively. 


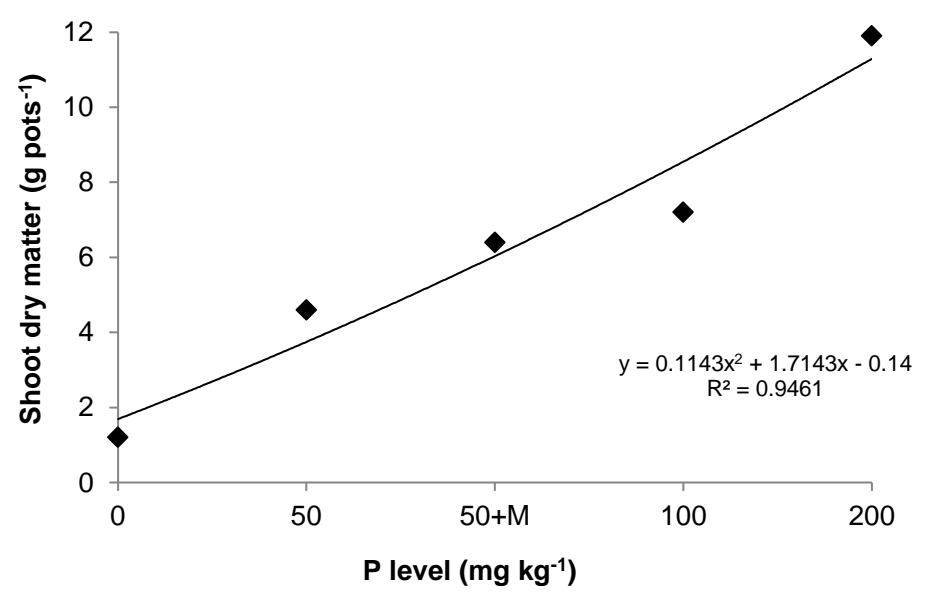

Figure 1 - Relations between dry matter of shoots of maize, doses of phosphorus and mycorrhization (+M).

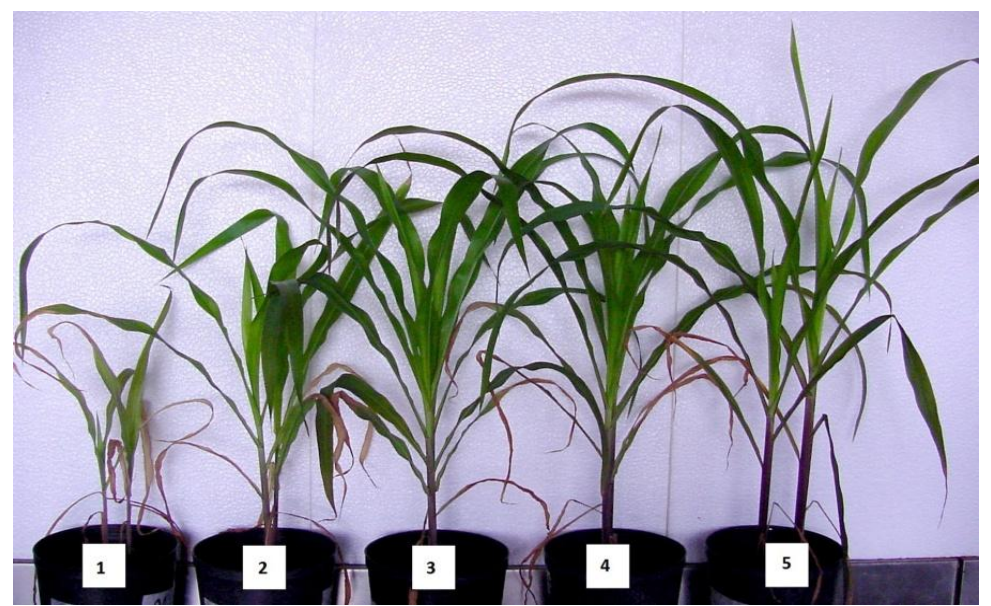

Figure 2 - Growth of maize plants in response to doses of phosphorus and mycorrhization $(+\mathrm{M})$. $1-0 \mathrm{mg} \mathrm{kg}^{-1}$ of $P ; 2-50 \mathrm{mg} \mathrm{kg}^{-1}$ of $P ; 3-50 \mathrm{mg} \mathrm{kg}^{-1}$ of $P+M ; 4-100 \mathrm{mg} \mathrm{kg}^{-1}$ of $P ; 5-200 \mathrm{mg} \mathrm{kg}^{-1}$ of $P$.

The treatment with $50 \mathrm{mg} \mathrm{kg}^{-1}$ of $P$ and inoculation didn't present significant differences on shoots dry matter when compared to the same treatment without inoculation and the treatment with $100 \mathrm{mg} \mathrm{kg}^{-1}$ of $\mathrm{P}$. However, the level of phosphorus in the shoots was significantly higher in the inoculated treatment than in the non-inoculated $+50 \mathrm{mg} \mathrm{kg}^{-1}$ of $P$ treatment (Table 1, Figure 3).

The levels of phosphorus in the shoots increased with application of this nutrient (Table 1). Comparing the treatments with and without phosphorus application, the increase in the level of $\mathrm{P}$ in the shoots were $40 \%, 56 \%, 50 \%$, and $47 \%$, in the treatments with $50 \mathrm{mg} \mathrm{kg}^{-1}$ of $P$, $50 \mathrm{mg} \mathrm{kg}^{-1}$ of $\mathrm{P}$ and inoculation, $100 \mathrm{mg} \mathrm{kg}^{-1}$ of $P$ and $200 \mathrm{mg} \mathrm{kg}^{-1}$ of $\mathrm{P}$, respectively. The phosphorus content in shoots increased until approximately $150 \mathrm{mg} \mathrm{kg}^{-1}$ of fertilization and started to decrease beyond this point.

Concerning the other nutrients, there was significant differences in the levels of $\mathrm{K}, \mathrm{Mg}$ and $\mathrm{Mn}$ in the leaves, which were probably related to interactions between these nutrients and phosphorus. Results show that $\mathrm{K}$ and $\mathrm{Mn}$ decrease in content in the leaves when levels of $P$ are increased in the soil. However, the opposite is observed for $\mathrm{Mg}$; $\mathrm{Mg}$ content increases with application of phosphorus in the soil. The treatment with mycorrhizae (T3) differed in $\mathrm{P}$ and $\mathrm{Mg}$ levels in the shoots when compared with the same level of $P$ and without inoculation (T2) (Table 1), showing the positive effect of mycorrhization to nutrient uptake by maize.

The $P$ accumulation in shoots was higher in the treatment with application of $400 \mathrm{~kg} \mathrm{ha}^{-1}$ of fertilizer. The treatments with application of $100 \mathrm{~kg} \mathrm{ha}^{-1}$ and mycorrhiza and $200 \mathrm{~kg} \mathrm{ha}^{-1}$ without mycorrhiza didn't differ significantly. The treatment with mycorrhiza was more efficient in absorbing available $\mathrm{P}$ and converting it to shoot dry matter, according to the $\mathrm{P}_{\mathrm{ac}}: \mathrm{P}_{\mathrm{av}}$ ratio (Table 2, Figure 3).

The number of spores and the colonization percentage of the roots were significantly higher in the inoculated treatment in comparison to the non-inoculated treatments (Table 3 ). 
Table 1 - Shoot dry matter (SDM) and leaf levels of nutrients, in response to doses of phosphorus fertilization and to mycorrhization.

\begin{tabular}{|c|c|c|c|c|c|c|c|c|c|c|c|}
\hline \multirow{2}{*}{$\begin{array}{l}\text { P levels } \\
\left(\mathrm{mg} \mathrm{kg}^{-1}\right)\end{array}$} & SDM & $\bar{P}$ & $\overline{\mathrm{N}}$ & $\mathrm{K}$ & $\mathrm{Ca}$ & $\overline{M g}$ & $\bar{S}$ & $\overline{Z n}$ & $\mathrm{Cu}$ & $\overline{\mathrm{Mn}}$ & $\mathrm{B}$ \\
\hline & $\mathrm{t} \mathrm{ha}^{-1}$ & & & $(\mathrm{gl}$ & & & & \multicolumn{4}{|c|}{ - $\left(\mathrm{mg} \mathrm{kg}^{-1}\right)$} \\
\hline 0 & $1.22 \mathrm{c}$ & $0.97 \mathrm{c}$ & $17.3 a$ & $47 a$ & $12.1 \mathrm{a}$ & $3.6 \mathrm{~b}$ & $2.7 \mathrm{a}$ & $33 a$ & $12 a$ & $62 \mathrm{ab}$ & $15 a$ \\
\hline 50 & $4.60 \mathrm{~b}$ & $1.63 b$ & $19.0 \mathrm{a}$ & $41 \mathrm{~b}$ & $13.3 a$ & $4.0 \mathrm{~b}$ & $2.7 \mathrm{a}$ & $33 a$ & $14 a$ & $66 a$ & $15 a$ \\
\hline $50+\mathrm{M}^{2}$ & $6.37 \mathrm{~b}$ & $2.23 a$ & $20.3 a$ & $42 a b$ & $13.5 \mathrm{a}$ & $4.9 a$ & $2.8 \mathrm{a}$ & $38 a$ & $13 a$ & $59 a b$ & $13 a$ \\
\hline 100 & $7.18 b$ & $1.93 \mathrm{ab}$ & $18.7 \mathrm{a}$ & $38 b$ & $13.1 \mathrm{a}$ & $4.8 \mathrm{a}$ & $2.6 a$ & $35 a$ & $17 a$ & $51 b$ & $13 a$ \\
\hline 200 & $11.88 \mathrm{a}$ & $1.83 \mathrm{ab}$ & $18.0 \mathrm{a}$ & $25 c$ & $12.0 \mathrm{a}$ & $4.9 a$ & $2.5 \mathrm{a}$ & $29 a$ & $15 a$ & $52 \mathrm{ab}$ & $12 a$ \\
\hline CV (\%) & 15.63 & 8.35 & 10.07 & 5.33 & 7.43 & 5.35 & 8.33 & 15.37 & 17.78 & 8.84 & 9.95 \\
\hline
\end{tabular}

"Values followed by the same letter in the column don't differ significantly (Tukey $p>0.05$ ); ${ }^{2)}$ Treatment with inoculation by Gigaspora margarita.

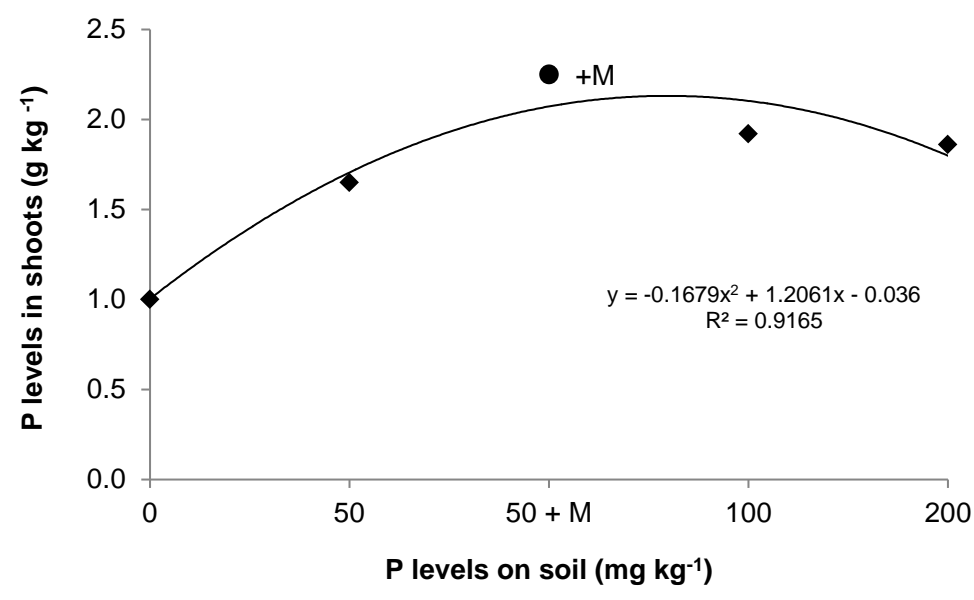

Figure 3 - Phosphorus content in shoots in response to doses of phosphorus fertilization and mycorrhization.

Table 2 - $\mathrm{P}$ accumulation $(\mathrm{Pac})$ in the shoot, $\mathrm{P}$ avalailable in the soil ((Pav) and ratio Pac:Pav in response to doses of phosphorous fertilizer and mycorrhization.

\begin{tabular}{lccc}
\hline $\begin{array}{c}\text { Treatments } \\
\left(\mathrm{kg} \mathrm{ha}^{-1}\right)\end{array}$ & $\begin{array}{r}\mathrm{P} \text { accumulation on shoots }\left(\mathrm{P}_{\mathrm{ac}}\right) \\
\left(\mathrm{kg} \mathrm{ha}^{-1}\right)\end{array}$ & $\begin{array}{c}\mathrm{P} \text { available on soil }\left(\mathrm{P}_{\mathrm{av}}\right)^{2} \\
\left(\mathrm{~kg} \mathrm{ha}^{-1}\right)\end{array}$ & $\mathrm{P}_{\mathrm{ac}}: \mathrm{P}_{\mathrm{av}}$ \\
\hline $0(\mathrm{~T} 1)$ & $1.22 \mathrm{~d}$ & $2.85 \mathrm{c}$ & $0.43 \mathrm{c}$ \\
$100(\mathrm{~T} 2)$ & $7.50 \mathrm{c}$ & $4.69 \mathrm{c}$ & $1.61 \mathrm{~b}$ \\
$100+\mathrm{M}(\mathrm{T} 3)$ & $14.28 \mathrm{~b}$ & $5.83 \mathrm{bc}$ & $2.45 \mathrm{a}$ \\
$200(\mathrm{~T} 4)$ & $13.77 \mathrm{~b}$ & $7.98 \mathrm{~b}$ & $1.73 \mathrm{~b}$ \\
$400(\mathrm{~T} 5)$ & $22.10 \mathrm{a}$ & $18.25 \mathrm{a}$ & $1.22 \mathrm{~b}$ \\
\hline CV $(\%)$ & 15.61 & 10.36 & 17.08 \\
\hline
\end{tabular}

Means followed by the same letter, in the column, don't differ significantly (Tukey $p>0.05$ ); ${ }^{2}$ Mehlich-1 extraction method.

Table 3 - Number of spores (ES) of arbuscular mycorrhizal fungi in the soil and corn root colonization $(\mathrm{CR})$ in response to doses of phosphorous fertilizer and mycorrhization.

\begin{tabular}{ccc}
\hline Treatments & $\begin{array}{c}\mathrm{ES}^{2} \\
\left(\mathrm{n}^{\circ} 50 \mathrm{~g}^{-1}\right)\end{array}$ & $\begin{array}{c}\mathrm{CR}^{3} \\
(\%)\end{array}$ \\
\hline T1 & $5 \mathrm{~b}$ & $6 \mathrm{~b}$ \\
T2 & $9 \mathrm{~b}$ & $12 \mathrm{~b}$ \\
T3 & $176 \mathrm{a}$ & $68 \mathrm{a}$ \\
\hline
\end{tabular}

Means followed by the same letter, in the column, don't differ significantly (Tukey $p>0.05$ ); ${ }^{2)}$ Treatment with inoculation by Gigaspora margarita; ${ }^{3)}$ For statistical analysis, the data of the spores were transformed into $y=(x+0.5)^{0.5}$, and the data of root colonization, into $y=\operatorname{arc~sen}(x / 100)^{0.5}$. 
The effect of phosphorus fertilization on maize yield in Oxisols was observed by several authors (SOUZA et al. 1999; LUCENA et al. 2000; ALVES et al. 2002; OLIVEIRA et al. 2009).

The increase in the yield of dry matter in the treatments with phosphorus proves that the application of phosphate fertilizers in Cerrado soils promotes significant increments in the yields of the crops. The response to phosphate fertilization depends on, among other factors, the availability of phosphorus and other nutrients in the soil, the specie and variety of the cultivated plant, and the environment conditions (SOUSA et al. 2004).

In the comparison among the treatments with a dose of $50 \mathrm{mg} \mathrm{kg}^{-1}$ of $\mathrm{P}$ and with this same dose and inoculation, there was no significant difference in the dry matter yield. In the initial periods of the plant growth, the absence of response in the treatment with inoculation can be attributed to the seeds own nutritional reserves, to the period of establishment of the symbiosis, to the differences of conformations of the root system, and to the mycotrophic condition (mycorrhizal dependency) of the plant (ZANGARO et al., 2005; PASQUALINI et al., 2007). CAMPOS et al. (2010), testing maize genotypes and response to mycorrhizae in a greenhouse, observed that some genotypes showed no increases in shoots dry matter production, similarly to this study.

CELEBI et al. (2010), studying the effect of arbuscular mycorrhizal fungi in maize crop under different irrigation regimes and without varying phosphorus, obtained higher mean values of dry matter yield in treatments with mycorrhiza inoculation than the treatments without inoculation. These results show that in field conditions the presence of mycorrhizae provides increase in plant development and, possibly, higher grain yield.

The treatments with a dose of $50 \mathrm{mg} \mathrm{kg}^{-1}$ and inoculation and with a dose of $100 \mathrm{mg} \mathrm{kg}^{-1}$ without inoculation, when compared, didn't show significant differences concerning the production of dry matter. This absence of difference can be explained by the higher efficiency of $\mathrm{P}$ absorption on the inoculated maize, shown by the high $P_{a c}: P_{a v}$ of the inoculated treatment, which consequently increased shoot dry matter and fertilization efficiency. MIRANDA et al. (1984) in an experiment with sorghum observed similar behavior. The plants with mycorrhiza and planted in natural soil with $25 \mathrm{mg} \mathrm{kg}^{-1}$ of phosphorus grew similarly to those without inoculation and planted in soil with $50 \mathrm{mg} \mathrm{kg}^{-1}$ of phosphorus.

REIS et al. (2008) obtained different responses in shoots dry matter comparing inoculated and non-inoculated treatments with low and high $P$ application. The authors didn't observed differences between the treatments with same doses of $\mathrm{P}$ with or without mycorrhization, but comparing the treatment with low $\mathrm{P}$ and mycorrhiza and treatment with high $\mathrm{P}$ without mycorrhiza, the second one presented higher shoot dry matter.

The high absorption of $\mathrm{P}$ by the inoculated plants didn't result in higher shoots dry matter, as ORTAS \& AKPINAR (2011) and GILL et al. (2013) also obtained. This can be explained by the occurrence of luxury uptake of phosphorus by inoculated plants. Others factors can also contribute to this disproportion, as the consumption of carbohydrates by the mycorrhizas or by the short period of development on greenhouse (MOSSE, 1973; PAIRUNAN et al., 1980; MIRANDA et al., 1984). The efficiency of the endomycorrhizal association in the absorption of $P$ varies according to the plant, the soil, and the fungi specie used (MIRANDA, 2008).

In this study, the treatment with high application of $P\left(200 \mathrm{mg} \mathrm{kg}^{-1}\right)$ showed an increase on the shoot dry matter, despite the reduced absorption of this nutrient, observed by the quadratic equation. LUCENA et al. (2000) observed different behavior in experiment with doses of nitrogen and phosphorus and maize response in Yellow-Red Oxisol. The authors showed that the applications upper to $177.3 \mathrm{~kg}$ $\mathrm{ha}^{-1}$ of $\mathrm{P}_{2} \mathrm{O}_{5}\left(77.4 \mathrm{~kg} \mathrm{ha}^{-1}\right.$ de $\left.\mathrm{P}\right)$ reduces the plant height and the grain yield. BARRETO \& FERNANDES (2002) observed that the increase in $\mathrm{P}$ content in shoots showed a linear response to different doses of $\mathrm{P}_{2} \mathrm{O}_{5}$, diverging from the results of this study (quadratic response). However, these authors obtained a quadratic response in grain yield.

Concerning the differences in the nutrients uptake, the level of potassium on the shoots decreased with application of P. REINBOTT \& BLEVINS (1991) also observed this reduction of $\mathrm{K}$ in wheat seedlings. The level of magnesium on the shoots increases with application of $P$, behavior already described in the literature (ADAMS, 1980; MALAVOLTA, 2004; ROBSON \& PITMAN, 1983).

Some authors described the effect of high level of $P$ available on plant in induce deficiencies of micronutrients, such as zinc ( $\mathrm{Zn})$ and manganese $(\mathrm{Mn})$, in species like maize (ADRIANO \& MURPHY, 1970; ADRIANO et al., 1971; LANGIN et al., 1962). The high amount of $P$ application didn't decrease the $\mathrm{Zn}$ level on the shoot in this study. NICHOLS et al. (2012) obtained direct correlation between $\mathrm{P}$ and $\mathrm{Zn}$ concentration, confronting the commonly held belief that high $P$ availability reduces $\mathrm{Zn}$ uptake in maize.

The mycorrhizal association can result in higher efficiency of root absorption, not only of phosphorus, but also other nutrients as nitrogen, copper, and zinc (LIU et al., 2000). This better 
efficiency is due to the higher area and better distribution of the root absorption surface of the plants. However, in this study, the efficiency was observed only in $\mathrm{P}$ uptake, shown by the $\mathrm{P}_{\mathrm{ac}}: \mathrm{P}_{\mathrm{av}}$ ratio, probably due to the reduced development period in the greenhouse.

The number of spores found in the noninoculated treatments suggests the resistance of some native species to sterilization. The colonization percentage of the roots was higher in the treatment with mycorrhization, because the number of native spores present in the non-inoculated treatments wasn't enough to promote the significant colonization of the roots of the corn plants. The autoclaving presents high efficiency in reduce the microorganisms population, although occasioning some alterations on soil chemical properties (LOPES \& WOLLUM, 1976).

\section{Conclusion}

In the conditions of this experiment it's concluded that:

The inoculated treatment was statically equal to the treatments with 50 and $100 \mathrm{mg} \mathrm{kg}^{-1}$ of $P$ in dry matter of shoots, which means economy in the application of phosphate fertilizer.

Treatments inoculated with arbuscular mycorrhizal fungi showed higher proportion of $P$ accumulation and $P$ available in the soil, showing higher efficiency in phosphorus absorption.

The treatment with high application of $P$ showed the highest shoot dry matter, despite the lower absorption of that nutrient.

The phosphorus had an antagonistic effect with potassium and manganese and synergistic effect with magnesium. The phosphorus didn't interact with other quantified nutrients.

The application of $119.6 \mathrm{~kg} \mathrm{ha}^{-1}$ of $\mathrm{P}$ provides the highest phosphorus accumulation on shoots.

\section{References}

ABBOTT, L. K.; ROBSON, A. D. The impact of agricultural practices on mycorrhizal fungi. In: PANKHURST, C. E.; DOUBE, B. M.; GUPTA, V. V. S. R.; GRACE, P. R. (Coord.). Soil biota: management in sustainable farming systems. Victoria: CSIRO, 1994. p.88-95.

ADAMS, F. Interactions of phosphorus with other elements in soil and plants. In: KHASAWNNEH, F. E.; SAMPLE, E. C.; KAMPRATH, E. J. (Coord.). The role of phosphorus in agriculture. Madison: American Society of Agronomy, 1980. p.655-680.

ADLER, P. R.; WILCOX, G. E. Rapid perchloric acid digest methods for analysis of major elements in plant tissue. Communication in Soil Science and Plant Analysis, New York, v.16, n.11, p.1153-1163, 1985.
ADRIANO, D. C.; MURPHY, L. S. Effects of ammonium polyphosphates on yield and chemical composition of irrigated corn. Agronomy Journal, Madison, v.62, n.5, p.561-567, 1970.

ADRIANO, D. C.; PAULSEN, G. M.; MURPHY, L. S. Phosphorus-iron and phosphorus-zinc relationships in corn seedlings as affected by mineral nutrition. Agronomy Journal, Madison, v.63, n.1, p.36-39, 1971.

ALGUACIL, M. M.; LUMINI, E.; ROLDAN, A.; SALINAS-GARCIA, J. R.; BONFANTE, P.; BIANCIOTTO, V. The impact of tillage practices on arbuscular mycorrhizal fungal diversity in subtropical crops. Ecological Applications, Washington, v.18, n.2, p.527-536, 2008.

ALVES, W. A.; ALBUQUERQUE, J. H.; OLIVEIRA, F. A.; CAVALCANTE, L. F.; SOUZA, C. C. Manejo da água disponível no solo e adubação fosfatada: efeito sobre a cultura do milho. Revista Brasileira de Engenharia Agrícola e Ambiental, Campina Grande, v.6, n.2, p.247-251, 2002.

BARRETO, A. C.; FERNANDES, M. F. Produtividade e absorção de fósforo por plantas de milho em função de doses e modos de aplicação de adubo fosfatado em solo de tabuleiro costeiro. Revista Brasileira de Ciência do Solo, Viçosa, MG, v.26, n.1, p.151-156, 2002.

BETHLENFALVAY, G. J.; LINDERMAN, R. G. Mycorrhizae in sustainable agriculture. Madison: ASA/CSSA/SSSA, 1992.124p.

BEVER, J. D.; MORTON, J. B.; ANTONOVICS, J.; SCHULTZ, P. A. Host-dependent sporulation and species diversity of arbuscular mycorrhizal fungi in a mown grassland. The Journal of Ecology, Oxford, v.84, n.1, p.71-82, 1996.

BONONI, V. L. R.; TRUFEM, S. F. B. Endomicorrízas vesículo-arbusculares do cerrado da Reserva Biológica de Moji-Guaçu, SP, Brasil. Rickia, São Paulo, v.10, n.1, p.55-84, 1990.

BRUNDRETT, M. C. Mycorrhizas in natural ecosystems. Advances in Ecological Research, London, v.21, n.1, p.171-313, 1991.

CAMPOS, D. T. S.; ANDRADE, J. A. C.; CASSIOLATO, A. M. R. Crescimento e micorrização de genótipos de milho em casa de vegetação. Bragantia, Campinas, v.69, n.3, p.555-562, 2010.

CELEBI, S. Z., DEMIR, S., CELEBI, R., DURAK, E. D., YILMAZ, I. H. The effect of Arbuscular Mycorrhizal Fungi (AMF) applications on the silage maize (Zea mays L.) yield in different irrigation regimes. European Journal of Soil Biology, Montrouge, v.46, n.1, p.302-305, 2010. 
COSTA, T. A.; PINTRO, J. C.; SILVA, E. S.; COSTA, S. M. G. Influência da inoculação de fungos micorrízicos arbusculares, da acidez do solo e de fontes de fósforo no crescimento do milho. Acta Scientiarum, Maringá, v.24, n.5, p.1583-1590, 2002.

ERNANI, P.R.; BAYER, C.; MAESTRI, L. Corn yield as affected by liming and tillage system on an acid Brazilian Oxisol. Agronomy Journal, Madison, v.94, n.2, p.305-309, 2002.

ESPÍNDOLA, J. A. A.; ALMEIDA, D. L.; GUERRA, J. G. M.; SILVA, E. M. R.; SOUZA, F. A. Influência da adubação verde na colonização micorrízica e na produção da batata-doce. Pesquisa Agropecuária Brasileira, Brasília, v.33, n.3, p.339-347, 1998.

GERDEMANN, J. W.; NICOLSON, T. H. Spores of mycorrhizal endogene species extracted from soil by wet sieving and decanting. Transactions of the British Mycological Society, London, v.46, p.235-244, 1963.

GILL, A. A. S; BHADORIA, P. B. S; SADANA, U. $S$. Effect of mycorrhizal infection on phosphorus efficiency of maize (Zea mays L.) cultivars. Proceedings of the National Academy of Sciences India Section B: Biological Sciences, Allahabad, v.83, n.2, p.147-157, 2013.

VAN DER HEIJDEN, M. D. A; WIEMKEN, A.; SANDERS, I. R. Different arbuscular mycorrhizal fungi alter coexistence and resource distribution between co-occurring plants. New Phytologist, Cambridge, v.157, n.3, p.569-578, 2003.

JASPER, D. A.; ABBOT, L. K.; ROBSON, A. D. The effect of soil disturbance on vesiculararbuscular mycorrhizal fungi in soils from different vegetation types. New Phytologist, Cambridge, v.118, n.3, p.471-476, 1991.

JOHNSON, N. C.; TILMAN, D.; WEDIN, D. Plant and soil controls on mycorrhizal fungal communities. Ecology, Dunhan, v.73, n.6, p.2034-2042, 1992.

LANGIN, E. J.; WARD, R. C.; OLSON, R. A.; ROADES, H. F. Factors responsible for poor response of corn and grain sorghum to phosphate fertilization. II. Lime and phosphate replacement effects on $\mathrm{P}-\mathrm{Zn}$ relations. Proceedings of the Soil Science Society of America, Madison, v.26, n.1, p.574-578, 1962.

LIU, A.; HAMEL, C.; HAMILTON, R. I; MA, B. L.; SMITH, D. L. Acquisition of $\mathrm{Cu}, \mathrm{Zn}, \mathrm{Mn}$ and Fe by mycorrhizal maize (Zea mays L.) grown in soil at different $P$ and micronutrient levels. Mycorrhiza, Berlin, v.9, n.6, p.331-336, 2000.

LOBATO, E. Adubação fosfatada em solos da Região Centro-Oeste. In: OLIVEIRA, A. J.; LOURENÇO, S.; GOEDERT, W. J. (Ed). Adubação fosfatada no Brasil. Brasília: EMBRAPA/DID, 1982. p.201-240.
LOPES, A. S.; WOLLUM, A. G. Comparative effects of methylbromide, propylene oxide, and autoclave sterilization on specific soil chemical characteristcs. Turrialba, v.26, p.351-355, 1976.

LUCENA, L. F. C.; OLIVEIRA, F. A. Z.; SILVA; I. F.; ANDRADE, A. P. Resposta do milho a diferentes dosagens de nitrogênio e fósforo aplicados ao solo. Revista Brasileira de Engenharia Agrícola e Ambiental, Campina Grande, v.4, n.3, p.334-337, 2000.

MALAVOLTA, E. O fósforo na planta e interações com outros elementos. In: YAMADA, T.; ABDALLA, S. R. S. (Ed.) Fósforo na agricultura brasileira. Piracicaba: POTAFOS, 2004. p.35-105.

MARTINS, C. R.; MIRANDA, J. C. C.; MIRANDA, L. N. Contribuição de fungos micorrízicos arbusculares nativos no estabelecimento de Aristida setifolia Kunth em áreas degradadas do Cerrado. Pesquisa Agropecuária Brasileira, Brasília, v.34, n.4, p.665-674, 1999.

MIRANDA, J. C. C. Micorriza arbuscular, crescimento das plantas e produtividade das culturas em solos do Bioma Cerrado. In: MIRANDA, J. C. C. de. Cerrado: micorriza arbuscular: ocorrência e manejo. Planaltina, DF: Embrapa Cerrados, 2008. p.87-132.

MIRANDA, J. C. C.; MIRANDA, L. N. Micorriza arbuscular. In: VARGAS, M. A. T.; HUNGRIA, M. (Ed.). Biologia dos solos dos cerrados. Brasília: Embrapa Cerrados, 1997. p.67-123.

MIRANDA, J. C. C.; SOUSA, D. M. G.; MIRANDA, L. N. Influência de fungos endomicorrízicos vesicular-arbusculares na absorção de fósforo e no rendimento de matéria seca de plantas de sorgo. Revista Brasileira de Ciência do Solo, Viçosa, MG, v.8, n.1, p.31-36, 1984.

MIRANDA, J. C. C.; VILELA, L.; MIRANDA, L. N. Dinâmica e contribuição da micorriza arbuscular em sistemas de produção com rotação de culturas. Pesquisa Agropecuária Brasileira, Brasília, v.40, n.10, p.1005-1014, 2005.

MIRANDA, J. C. C.; MIRANDA, L. N. Contribuição da micorriza arbuscular para a produtividade e sustentabilidade nos sistemas de produção com plantio direto e convencional no Cerrado. Planaltina: Embrapa Cerrados, 2007. 6p. (Comunicado Técnico, 134).

MOSSE, B. Advances in the study of vesiculararbuscular mycorrhiza. Annual Review of Phytopathology, Palo Alto, v.11, p.171-196, 1973.

MIRANDA, J. C. C.; MIRANDA, L. N.; VILELA, L.; VARGAS, M. A.; CARVALHO, A. M. Manejo da micorriza arbuscular por meio da rotação de culturas nos sistemas agrícolas do Cerrado. Planaltina: Embrapa Cerrados, 2001. 3p. 
MOSSE, B. Vesicular-arbuscular mycorrhizal research for Tropical Agriculture. Hawaii: Hawaii Institute of Tropical Agricultural and Human Resources, University of Hawaii, 1981. 82p. (Research Bulletin, 194).

NICHOLS, B. A.; HOPKINS, B. G.; JOLLEY VON, D.; WEBB, B. L.; GREENWOOD, B. G.; BUCK, J. R. Phosphorus and zinc interactions and their relationships with other nutrients in maize grown in chelator-buffered nutrient solution. Journal of Plant Nutrition, New York, v.35, n.1, p.123-141, 2012.

NOVAIS, R. F.; SMYTH, T. J. Fósforo em solo e planta em condições tropicais. Viçosa: Universidade Federal de Viçosa, 1999. 319p.

OLIVEIRA, F. A.; CAVALCANTE, L. F.; SILVA, I. F.; PEREIRA, W. E.; OLIVEIRA, J. C.; COSTA FILHO, J. F. Crescimento do milho adubado com nitrogênio e fósforo em um Latossolo Amarelo. Agrária, Recife, v.4, n.3, p.238-244, 2009.

ORTAS, I.; AKPINAR, Ç. Response of maize genotypes to several mycorrhizal inoculums interms of plant growth, nutrient uptake and spore production. Journal of Plant Nutrition, New York, v.34, n.1, p.970-987, 2011.

PAIRUNAN, A. K.; ROBSON, A. D.; ABBOTT, L. $K$. The effectiveness of vesicular-arbuscular mycorrhizas in increasing growth and phosphorus uptake of subterranean clover from phosphorus sources of different solubilities. New Phytologist, Cambridge, v.84, n.2, p.327-338, 1980.

PASQUALINI, D.; UHLMANN, A.; STURMER, S. L. Arbuscular mycorrhyzal fungal communities influence growth and phosphorus concentration of woody plants species from the Atlantic rain forest in South Brazil. Forest Ecology and Management, Amsterdam, v.245, p.148-145, 2007.

PHILLIPS, J. M.; HAYMAN, D. S. Improved procedures for clearing roots and staining parasitic and vesicular-arbuscular mycorrhyzal fungi for rapid assessment of infection. Transactions of the British Mycological Society, Cambridge, v.55, n.1, p.158-161, 1970.

REINBOTT, T. M.; BLEVINS, D. G. Phosphate interaction with uptake and leaf concentration of magnesium, calcium, and potassium in winter wheat seedlings. Agronomy Journal, Madison, v.83, n.6, p.1043-1046, 1991.

REIS, E. F; CARNEIRO, M. A. C; SAGGINJÚNIOR, O. J.; ROTTA, D. A. SOUSA, M. Y. Absorção de fósforo em doze genótipos de milho inoculados com fungo micorrízico arbuscular em solo de cerrado. Ciência Rural, Santa Maria, v.38, n.9, p.2441-2447, 2008.
RILLIG, M. C.; MUMMEY, D. L. Mycorrhizas and soil structure. New Phytologist, Cambridge, v.171, n.1, p.41-53, 2006.

ROBSON, A. D.; PITMAN, M. G. Interactions between nutrients in higher plants. In: LAUCHLI, A.; BIELESKI, R.L. Encyclopedia of plant physiology. Berlin: Springer-Verlag, 1983. p.147-180.

SANCHEZ, P. A.; SALINAS, J. G. Low-input technology for managing Oxisols and Ultisols in tropical America. Advances in Agronomy, New York, v.34, p.279-406, 1981.

SAS Institute. SAS/STAT: User's guide, version 8.1, Cary, 1999-2000. v.1, 943p.

SIEVERDING, E. Vesicular-arbuscular mycorrhiza management in tropical agrosystems. Eschborn: Deutsche Gesellschaft für Technische Zusammenarbeit (GTZ), 1991. 371p.

SILVA, F. C. Manual de análises químicas de solos, plantas e fertilizantes. Rio de Janeiro: Embrapa Solos; Campinas: Embrapa Informática Agropecuária, 1999. 370p.

SMITH, S. E.; READ, D. J. Mycorrhizal symbiosis. London: Academic Press, 1997. 605p.

SOUSA, D. M. G.; LOBATO, E. ; REIN, T. A. Adubação com fósforo. In: SOUSA, D. M. G; LOBATO, E. Cerrado: correção do solo e adubação. 2.ed. Brasília: Embrapa Informação Tecnológica, 2004. p.147-168.

SOUZA, E. C. A.; COUTINHO, L. M.; NATALE, W.; BARBOSA, J. C. Respostas do milho à adubação com fósforo e zinco. Pesquisa Agropecuária Brasileira, Brasília, v.33, n.7, p.1031-1036, 1998.

STADDON, P. L.; THOMPSON, K.; JAKOBSEN, I.; GRIME, J. P.; ASKEW, A. P.; FITTER, A. H. Mycorrhizal fungal abundance as affected by longterm climatic manipulations in the field. Global Change Biology, Oxford, v.9, p.186-194, 2003.

SYLVIA, D. M.; WILLIAMS, S. E. Vesiculararbuscular mycorrhizae and environmental stress. In: BETHLENFALVAY, G. J.; LINDERMAN, R. G. (Ed.). Mycorrhizae in sustainable agriculture. Madison: ASA Special Publication, 1992. p.101-124.

VARMA, A.; HOCK, B. Mycorrhiza: Structure, function, molecular biology and biotechnology. Berlin: Springer-Verlag, 1999. 704p.

ZANGARO, W.; NISHIDATE, F. R.; CAMARGO, F. R. S.; ROMAGNOLI, G. G.; VANDRESSEN, J. Relationships among arbuscular mycorrhizas, root morphology and seedling growth of tropical native woody species in southern Brazil. Journal of Tropical Ecology, London, v.21, n.5, p.529-540, 2005. 